\title{
Diversification of Woman Job at Informal Sector in Pare-Pare Nusantara Harbour
}

\author{
Asmirah \\ Faculty of Socilogy, University of Negeri, Makassar, Indonesia \\ Rabihatun Idris \\ University of Negeri, Makassar, Indonesia \\ Maria E.Pandu \\ University of Negeri, Makassar, Indonesia \\ Firdaus W. Suhaeb \\ University of Negeri, Makassar, Indonesia
}

Accepted: August 05, $2013 \quad$ Published: Sep 02, 2013
Doi:10.5296/jsr.v4i2.4213 $\quad$ URL: http://dx.doi.org/10.5296/jsr.v4i2.4213

\begin{abstract}
A great quantity of society whose economic problems caused the increasing of woman number who work for earning additional income. Man and woman share role in their household where woman play either housewife role or actively work out of the house to ear additional income. Working at informal sector is more flexible because it does not need certain requirements, except physical ability and a little financial capital. In order to be able to sustain life, women can choose many works at informal sector as a strategy earning sufficient income. Eventhough, factually still there many people does not live prosperously yet. Diversification job can be done due to the flexibility of each job. And the most important thing is the willingness to work and do not strive for gaining a big profit.
\end{abstract}

\section{Introduction}

It has been known that Economic problem is faced by the society especially to the people with low income caused the more increasing of woman who works for gaining income. The income has been gained is used for themselves and for their family needs. No more age restriction, we can meet easily women labor at various stage of age start from young until adult.

The role of gender which exists to almost people all over the World puts women responsible to household job is not strict anymore because there are many mowen nowadays who have a role to look for supplementary income away from home. It is normal and can be accepted if women play role as housewife while running a job at home. Because it does not ignore their main responsibility as housewives to take care husband, children, cooking, washing, cleaning 
house, and other household activities. Nowadays, there are many women look for supplementary income away from home and leave their household responsibility, even some of them work far away from home. The willingness to earn income and improve their social status in society become a motivation to look for job although it acrosses their residence.

Moreover, a woman who plays role as a single parent absolutely will undertake a role as a father and all at once as a mother either at home or away from home whose aim is just for her family life. Include unmarried women who have had responsibility to Finance their family, they will earn income as it is done by married women.

\section{Profile of Woman Worker}

The age of women worker at informal sector we met in Parepare harbour around $15-50$ years. Working age which is very productive will enable to increase work productivity. Most of them are still single because they are unmarried and divorce, and some of them are married. Almost all of them responsible to their family life.

In Education level, only some of them studied until high school. Mostly they only studied until elementary school level. There is not direct influence the different of their Education, job, and salary they get. Labor only did activities that rely on diligence without need to be professional. Talking about some region outside of pare-pare town. Among the workers are immigrant who have dwelt in this town and still There are some of them as circular immigrant. It is very interesting to be observed because there are women who are circular immigrant work to earn Money in Parepare town harbour. They are under 20 until 50 years of age.

All of woman worker at informal sector take this job as fixed job so that, much times used to do this job. They work when Three is a ship moors to harbour especially passenger ship. Just some of them who work everyday. Side walk traders will sell every day around the harbour and in harbour area. Peddlers look move back and forth when there is a passenger ship moors in quay. Informal activity is very crowded all day from morning to night where follow the ship's arrival and departure schedule. The ship has just arrived or will leave from and to one direction will bring passengers is a blessing for sidewalk seller and peddlers mainly before and after Holiday there are many passengers come to this harbour. This situation is used by them to get Money. Working start from morning until afternoon and they often sell until night. This activity has been being done since they did this activity.

Situation sues the women to give their contribution to earn supplementary income for household is a reality must be faced by women. They have to be able to undertake their function and role in household and outside activity to get Money. The use of time by women to do various role for family, household, earning Money and their role in society is the most important thing to be known more deeply about women profile who also look for Money and take care family and household.

Function sharing and woman role for family, household and work does not have certain restriction. There is role sharing flexibility between husband and wife. Job will be divided based on the opportunity and time owned by both of them. Cooking still becomes wife's responsibility, taking care Children and cleaning house can be done by husband together children. For single woman, they do household responsibility mainly cleaning house before 
going to work and rare to cook. Description about woman labors activity who work at informal sector can be said good enough because they have been doing their Activities for more than 6 months. Not only take care themselves, but also almost all of their time is used for working for the sake of family.

\section{Gender Role and Informal Sector}

One of social role done by people is gender role. Gender role is not based on gender but it can change time by time. The role can be exchanged between man and woman is changeable role due to Education Development, and the role of man and woman can be different in society. Various culture of Indonesia people also have various gender role which exist in each group of society. Gender role has different flexibility between one society to another society in accordance with people condition. Gender role is done at public sector with domestic sector, either Activities that earn money or social activity in society.

Basically, the role of man and woman can be exchanged each other, although in reality it is not easy to be exchanged. The role of gender which is exchanged each other between man and woman is usually related to Economic problem must be overcome together in order to be able to survive. It has been many women who make a longer time to look for Money if it is compared with men. The women work outside without any obstacle from out of themselves. It is not regarded as something contradictive with norm and value in society because people have accepted it.

Working at informal sector is not tight activity related to rule and requirement. So, the role sharing in family between man and woman can support each other. Flexible role sharing between man and woman also enable job diversification as a strategy to earn more income. Job diversification means an effort to find a job alternative which enable earning income to support another job.

According to Berger and Vutinic in Pitoyo (1999), the growth of informal sector can be analyzed by using The theory of Excess Labor Supply. This theory explains that the occurance of informal sector is caused by the disability of formal sector to accommodate all labors including unqualified labors. These labors then create their own job fields.

Sethuraman in Mannung and Effendi (1996) explained that Economic activity in informal sector is on small scale, the doers do not look for profit but the most important thing is getting job opportunity and income from their job. Their education is generally very low and they are unskilled. The explanation shows that how unqualified the labors who work at informal sector. So does the women who work as peddlers in Pare-Pare harbour. They will do job diversification if the income of being sidewalk traders and peddlers are not sufficient enough. This issue Force them to do any job specially those who rely on physical energy and little financial capital.

\section{The Meaning of Working for Woman}

Informal sector is becoming more and more develop along with the more increase of job seekers who are not accommodated at formal sector, the more job seeker create job for themselves. Including unmarried and married women. If it is observed more deeply, there are many women who do jobs what men do. Heavy jobs is also done by women such as working 
as a bus driver, mechanic who needs strong physic and mental. No more exception for the women to do certain jobs. All of job opportunity is same for both man and woman, including at informal sector as sidewalk Trader and peddler in Pare-pare harbour. As long as the job is not incompatible with norms in society women can do activity suitable with their capability. Generally, women who work at informal sector only rely on their power and regard that working is as a need must be undertaken. Working because there is something must be achieved and they expect that the job they do will give a better condition than before. They will be satisfied if the job is suitable with what they expect in working. They want to get more income and better level of life which must be followed by working hard, have to be ready to devote the time which is suitable with the condition the job done. Responsibility in household sometimes gets less attention if compared with time used to earn income. It is a consequence from a will to have better life for themselves and family.

Someone works because there is something wants to be achieved either social or Economic. Working as an informal sector Trade not only expecting award from the job like profit, but also she wants to have friendly social life through an effort of improving social status. So, someone has to work because of Economic needs does not mean as one consideration. Woman who is working outside is susceptible to Crime action mainly when working in the night, able to adapt to chosen job is the most important thing such as adapt to the norms of society where she works, the Labour, and policy maker who gave them a chance to do their activity. Feeling safe and comfort in working is something wanted.

Women as traders at informal sector in Parepare harbour are united in an organization of informal sector labor. Getting a problem in working place can be faced individually or organizationally. Self organizing in the group is a strategy to minimize the power gap among all traders and to ease the control is done by harbour authority.

There are specific characteristic that differentiate between peddlers and sidewalk traders are met in Parepare harbour.

a. Peddler

- Peddlers who offer Products to someone because they expect the Products will be bought.

- It is done in crowded public space

- The goods sold are not easy to break and light to brought anywhere

- Good at influence the buyer to buy the goods

- Doping it on foot

- Need small capital

b. Sidewalk Trader

- Having permanent place for Trading or does not mobile

The capital is bigger than peddlers, it looks from the number of goods sold

Waiting for buyer comes to them

Having flexibility to survive

A part of the goods are not belong to them, some of them can be returned if they are unsold.

Trading as a peddler does not need license from harbour Authority, but their existence as peddlers is known by their coordinator. Peddlers will report to coordinator only. Sidewalk 
traders have to have license which is published by harbour Authority if they want to be given a space for Trading.

\section{Diversification of Economic Activity}

Women Labour of informal sector in Parepare Harbour work as sidewalk trader and peddler. The number of labor is not stable everyday. Due to this condition, the harbour official is difficult to manage them orderly. On certain days, according to the ship arrival schedule, the harbour is very crowded. There are too many people come, they are the ship passengers, the people who take their family to the harbour or those who pick the passengers up. This crowd gives an opportunity to the sidewalk traders and peddlers working and earning Money.

Geographycal location of Parepare town connects some regencies in South Sulawesi. It is potential advantages to Parepare city to establish and improve the city as the service and trading area. In addition, Parepare has a crowd harbour with its trading enable this idea will come true. The effort to expand job field specially deceiting small and middle industry is exactly right and contributes many advantages toward the women labors who work as sidewalk traders and peddlers in the harbour. Eventhough, factually their life has not been prosperous yet, but it is more important for them to survive from the income.

a. The reason why Parepare harbour becomes a destination for the labors to look for job are :

b. The opportunity is possible for everyone

c. Trading as sidewalk traders and peddlers is possible to earn Money faster and easier.

d. Transportation fee is cheaper and the profit of Trading as peddler can cover it.

e. The similarity of culture and language with the visitors of the harbour enables them to Trade and do other activities easier.

f. The government policy supports the activity of the trader in Parepare Nusantara Harbour. The peddlers keep trying to fulfill their family needs and they never surrender eventhough they have to face many rules, obstacles and risks. And trading in the harbour is being their choice because it gives chance to earn income compared with trading at other places. They are women who have to work because it is a must, Rofi and Sukamdi (2001), Asmirah (1997). They have to look for whatever job, above all they can work and earn income, Rofi and Sukamdi (2001). According to Oey in Rofi and Sukamdi (2001) that trading sector became the last place for job seeker who wanted to earn income as soon as possible, because trading could be done without much capital, it did not have to be skilled, did not need high education, and easy to enter.

The ownership of working capital also differentiates sidewalk trader and peddler. Those who choose as permanent sidewalk traders do not trade mobile and generally have big working capital. They usually give capital loan to peddlers with profit sharing system. Peddlers usually acts as sidewalk traders especially if harbour Officer or ship owner does not permit them to Trade on ship. Peddlers admit that their goods can be sold soon and they can earn much more income when trade mobile than as sidewalk.

They do not Trade in the harbour everyday because the harbour is not always crowded with visitors as well. This case caused some peddler women did another job as an effort to do job diversification such as trading in Market or selling cakes at home. They have to do this in 
order to survive. They prefer doing this eventhough the income get is small to get nothing. They usually work as harvesting labor when harvest time comes until plant rice is begun, they also usually work to plant rice.

\section{Conclusion}

Informal sector in Parepare harbour specially sidewalk traders and peddlers will always exist because their existence can support the supply of visitor needs in harbour. In another side informal sector give a job opportunity to sidewalk traders and peddlers themselves.

The women who do this activity feel having responsibility of their family's Economic life, so that they always expect a job opportunity in the harbour becomes harbour Office policy. The owner of tie up ship in harbour quay is also expected to permit the peddlers to sell on ship. The government is expected to give them chance to sell under law Assurances so that sidewalk traders and peddlers do not get disturbing when trading in Parepare harbour.

\section{References}

Arief, Budiman. 1985. In Sexual Division of Labour. Jakarta: PT. Gramedia

Beavvoir De Simon. 2003. Second Sex. Female life. Library Promothea.

Boserup Ester. 1984. Role of Women in Economic Development. Jakarta. Obor Indonesia Foundation.

Coleman S. James. 2008. Basics of Social Theory. Bandung: Nusa Media

Damsar. 1997. Economic Sociology. Jakarta: PT. Raja Grafindo Persada.

Dubeck J. Paula and Borman Kathryn, Ed. 1997. Women and work. New Brunswick. New Jersey Rurgers University Press.

Irwan, Abdullah. 1997. Sangkan Peran Gender. Demography Research Centre Yogyakarta, University of Gajah Mada.

Joko, Pitoyo Agus. 1999. Street Vendor In Times of Crisis, Evidence for Population Policy. Yogyakarta: PPK. UGM.

Mansour, Fakih. 1997. Gender Analysis and Social Transformation. Yogyakarta: Pustaka Pelajar.

Maria, Rahayu S. 2004. Strategies Against Street Vendors PERDA No. 3 Tahun 2000. Denpasar: IKIP; PGRI.

Ollen Burger C. Jane \& Moore H. Helen. 2002. Sociology of Women, Jakarta: PT. Rineka Cipta.

Rofi \& Sukamdi. 2001. Shifting Economic Crisis and Female Labor Force Utilization; Cases in Jakarta. Yogyakarta: Demography Policy Research. UGM.

Smith Bonnie G. Ed. 2004. Women's History In Global Perspective, Volume 1. USA: American Historical Association.

Perspective, Volume 2. USA: American Historical Association.

Sukidin. 2009. Economic Sociology. Jember: Center For Society Study (CSS).

Setia M, Resmi. 2009. Urban Informal Economy; On A Case of Street Vendors in Bandung. Yayasan Akatiga Bandung. 